\title{
PENGARUH BAURAN PEMASARAN TERHADAP KEPUTUSAN KONSUMEN PERAWATAN KULIT PADA KLINIK KECANTIKAN DRM SKIN CLINIC DI MAKASSAR
}

\author{
Syarifuddin Arief \\ Dosen Dosen Politeknik Nasional, Makassar
}

\begin{abstract}
ABSTRAK
Penelitian ini bertujuan untuk mengetahui (1) pengaruh bauran pemasaran (produk, harga, lokasi, promosi, partisipan, proses, dan lingkungan fisik) terhadap keputusan konsumen perawatan kulit pada klinik kecantikan DRM Skin Clinic di Makassar secara simultan, (2) pengaruh bauran pemasaran (produk, harga, lokasi, promosi, partisipan, proses, dan lingkungan fisik) terhadap keputusan konsumen perawatan kulit pada klinik kecantikan DRM Skin Clinic di Makassar secara parsial, dan (3) faktor yang paling dominan dari bauran pemasaran (produk, harga, lokasi, promosi, partisipan, proses, dan lingkungan fisik) yang berpengaruh terhadap keputusan konsumen perawatan kulit pada klinik kecantikan DRM Skin Clinic di Makassar. Penelitian ini menggunakan data primer melalui survei sebanyak 96 orang pelanggan sebagai sampel dari seluruh jumlah populasi sebanyak 2.500 orang. Survei dilakukan dari bulan Desember 2012 sampai Februari 2013. Pengumpulan data yang digunakan dalam penelitian ini melalui kuesioner. Data dianalisis dengan metode deskriptif dan regresi linier berganda dan menggunakan program statistik SPSS versi 17. Hasil penelitian menunjukkan bahwa (1) secara simultan, bauran pemasaran (produk, harga, lokasi, promosi, partisipan, proses, dan lingkungan fisik) berpengaruh positif dan signifikan terhadap keputusan konsumen perawatan kulit pada klinik kecantikan DRM Skin Clinic di Makassar, (2) secara parsial, produk, lokasi, promosi, proses, dan lingkungan fisik berpengaruh positif dan signifikan, sedangkan harga berpengaruh negatif namun tidak signifikan dan partisipan berpengaruh positif namun tidak signifikan, dan (3) variabel yang paling dominan pengaruhnya terhadap keputusan konsumen perawatan kulit pada klinik kecantikan DRM Skin Clinic di Makassar adalah promosi.
\end{abstract}

Kata Kunci: bauran pemasaran, keputusan konsumen, perawatan kulit klinik kecantikan.

\section{PENDAHULUAN}

Makassar sebagai salah satu kota metropolitan di Indonesia merupakan lahan tersendiri bagi tumbuhnya bisnis layanan jasa seperti klinik-klinik kecantikan, dimana sudah menjadi kebutuhan atau rutinitas masyarakat metro untuk melakukan perawatan kesehatan dan kecantikan kulit. Bagi kaum hawa, keinginan tampil cantik, modis, dan trendi bagi kaum hawa sudah menjadi salah satu kebutuhan. Meskipun harus merogoh kocek lebih dalam untuk memenuhi kebutuhan ini, orang tetap mencari layanan perawatan kecantikan. Pertumbuhan tempat-tempat klinik layanan kecantikan menjadi salah satu bukti tingginya permintaan terhadap layanan kecantikan. 
114|Ad'ministrare, Vol. 3 No. 2, 2016

Berkembangnya jasa layanan perawatan kesehatan dan kecantikan kulit, disatu sisi tentunya membawa keuntungan bagi konsumen karena akan lebih banyak alternatif pilihan tempat bagi mereka yang ingin melakukan perawatan kesehatan dan kecantikan kulit, akan tetapi disisi lain akan menimbulkan ancaman bagi pengelola klinik-klinik kecantikan itu sendiri, karena harus menghadapi persaingan yang sangat ketat dalam memperebutkan jumlah pelanggan/konsumen yang ada.

DRM Skin Clinic merupakan sebuah klinik spesialis kulit dan kelamin yang beralamat di Jalan A.P. Pettarani, Kompleks Pettarani Center Blok A8 Makassar. Berikut ini adalah data tentang nama-nama jasa klinik kecantikan yang ada di Kota Makassar.

Tabel 1 Nama dan Alamat Klinik Kecantikan yang ada di Kota Makassar

\begin{tabular}{|l|l|l|}
\hline No. & \multicolumn{1}{|c|}{ Nama } & \multicolumn{1}{c|}{ Alamat } \\
\hline 1. & Klinik Perawatan Kulit Melliderma & Jln. Pelita raya I BI A/22 Mks \\
\hline 2. & Kose Beauty Cender & Jln. Arief rate No.7 Mks \\
\hline 3. & Klinik Kecantikan Madame Korner & Jln. Sungai Saddang No.12 Mks \\
\hline 4. & Miracle Aesthetic Clinic & Jln. Lamadukelleng No.58 Mks \\
\hline 5. & Shapeline Body Care Centre & Jln. Gn. Bulusaraung 4-D Mks \\
\hline 6. & Klinik Kecantikan Diet Sehat & Jln. Pasar Ikan No.23 Mks \\
\hline 7. & Klinik Kesehatan Kulit & Jln. Macan No.1 \\
\hline 8. & Klinik Makassar Dental care & Jln.Botolempangan No.82 Mks \\
\hline 9. & Klinik Kecantikan & $\begin{array}{l}\text { Jln. Bulu 2 Ruko Metro Square BI D-4 } \\
\text { Mks }\end{array}$ \\
\hline
\end{tabular}

Sumber: survei, data diolah, 2013

Semakin berkembang dan bertambahnya pelaku bisnis di bidang jasa klinik kecantikan ini, maka semakin membuat para pelakunya ditantang untuk dapat menciptakan differensiasi unik dan positioning yang jelas sehingga konsumen dapat membedakan dengan para pesaingnya. Kondisi pasar yang kompetitif dan dinamis akan mengakibatkan setiap perusahaan harus selalu mengamati persaingan dalam lingkungan bisnisnya. Dalam menghadapi lingkungan persaingan yang semakin kuat dan ketat, setiap perusahaan dituntut harus mampu mengoptimalkan sumber daya ekonominya guna meningkatkan daya saing produknya di pasar, serta mampu meramu serangkaian strategi pemasaran yang efektif dan selalu mengembangkan strategi pemasaran tersebut secara terus-menerus serta berkelanjutan. Hal ini dilakukan sebagai upaya untuk meraih keunggulan kompetitif terhadap para perusahaan pesaing.

Dari fenomena tersebut sebagai konsekuensinya, pihak marketer atau pengelola klinik kecantikan harus senantiasa memahami perilaku konsumen secara keseluruhan agar dapat mempertahankan kelangsungan hidupnya dan dapat merumuskan strategi pemasarannya dengan cepat dan tepat. Oleh karena klinik kecantikan merupakan perusahaan yang menghasilkan produk berupa jasa layanan maupun jasa penjualan yang harus dipasarkan kepada konsumen, maka dalam memilih sebuah klinik kecantikan sebagai tempat untuk perawatan kesehatan dan kecantikan kulit, konsumen banyak dipengaruhi oleh beberapa faktor, diantaranya adalah faktor bauran 
Syarifuddin Arief, Pengaruh Bauran Pemasaran Terhadap Keputusan Konsumen Perawatan Kulit Pada Klinik Kecantikan DRM Skin Clinic Di Makassar $\mid \mathbf{1 1 5}$

pemasaran yang terdiri dari 7P (yang meliputi : product, price, promotion, place, participant, process, dan physical evidence).

\section{KAJIAN TEORI}

\section{Bauran Pemasaran}

Pengertian bauran pemasaran tersebut diatas (empat $\mathrm{P}$ ) adalah bauran pemasaran untuk produk barang, sedangkan untuk bauran pemasaran jasa telah dikembangkan dan disesuaikan dengan karakteristik jasa itu sendiri. Menurut Payne (2000: 155) bauran pemasaran untuk jasa adalah $4 \mathrm{P}+3 \mathrm{P}$, yaitu product, price, place, promotion, people, process, dan proactive customer service (produk, harga, lokasi, promosi, penyampai jasa, proses, pelayanan proaktif terhadap pelanggan). Sedangkan menurut Yazid (1999:20) bauran pemasaran jasa adalah terdiri dari 7P's, yaitu: product, price, place, promotion, people or participant, physical evidence, dan process (produk, harga, lokasi, promosi, partisipan atau orang, bukti fisik, dan proses). Alma (1998:309), menegaskan bahwa elemen bauran pemasaran lembaga pendidikan terdiri atas $4 \mathrm{P}$ ditambah dengan $\mathrm{P}$ kelima yaitu: product, price, place, promotion, dan personal traits (produk, harga, lokasi, promosi, dan penyampai jasa).

Unsur-unsur bauran pemasaran yang digunakan dalam penelitian ini adalah seperti apa yang dikemukakan oleh Yazid, dimana bauran pemasaran jasa terdiri dari 7P, sebagai berikut: (1) Product (2) Price (3) Place (4) Promotion (5) People (participants) (6) Process dan (7) Physical Evidence (produk, harga, lokasi, promosi, penyampai jasa, proses, dan bukti fisik). Hal tersebut disebabkan karena keberhasilan penyelenggaraan suatu produk jasa tidak bisa lepas dari orangorang yang menyampaikan jasa tersebut, proses penyelenggaraan jasa itu sendiri, bagaimana jasa dan layanan diberikan kepada konsumen serta mutu jasa dipengaruhi oleh benda berujud dan perlengkapannya.

\section{Proses Keputusan Pembelian}

Proses keputusan pembelian bagi konsumen merupakan tahap yang penting dalam pengambilan suatu keputusan. Menurut Kotler (2005:170), ada lima tahap proses keputusan konsumen, dan langkah-langkahnya adalah sebagai berikut:

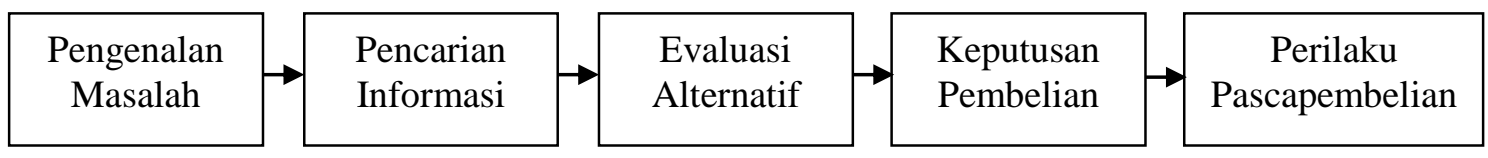

Gambar 1 Proses Keputusan Konsumen 
116|Ad'ministrare, Vol. 3 No. 2, 2016

\section{Pengenalan Masalah}

Pembeli memulai untuk melakukan proses pembelian ketika mereka mengenali sebuah masalah atau kebutuhan. Pembeli merasakan adanya perbedaan antara keadaan aktualnya dengan keadaan yang diinginkan. Kebutuhan tersebut dapat dicetuskan oleh rangsangan internal atau eksternal (Kotler,2005:171). Sedangkan menurut Yazid (1999:50) mengungkapkan bahwa perilaku konsumen jasa tidak berbeda dengan perilaku konsumen barang, karena pembelian atau penggunaan barang dan jasa hanya merupakan suatu sarana memenuhi kebutuhan. Sehingga dapat disimpulkan bahwa dalam pengenalan masalah ini konsumen menemukan masalah atau kebutuhan yang diinginkan dan selanjutnya merasakan keadaan nyata dengan apa yang diinginkannya.

\section{Pencarian Informasi}

Konsumen yang tergugah akan mengurangi pencarian informasi. Pencarian informasi ini bisa dibagi menjadi dua tingkat yaitu situasi pencarian informasi yang lebih ringan dinamakan perhatian yang menguat kemudian konsumen akan memasuki pencarian aktif informasi dimana konsumen benar-benar ingin mengetahui mengenai produk atau jasa yang dituju. Tiap informasi menjalankan fungsi yang berbeda dalam mempengaruhi keputusan pembelian (Kotler, 2005:171). Menurut Yazid (1999:51) terdapat lima sumber dasar pengumpulan informasi konsumen dalam keputusan pembelian jasa, yaitu:

1. Sumber-sumber internal. Konsumen mengaftifkan memori atau pengalaman yang tersimpan dibenaknya pada waktu memenuhi kebutuhan dan keinginannya tersebut. Proses pembelian ini disebut sebagai keputusan pembelian berdasar kebiasaan.

2. Sumber-sumber keluarga atau individu. Hal ini berasal dari keluarga, teman, sahabat, atau bahkan orang yang baru dikenal tetapi dipercayai.

3. Sumber-sumber pemasaran. Sumber ini mencangkup periklanan, tenaga penjualan (semua personel jada adalah tenaga penjualan suatu organisasi jasa), perantara atau waralaba, dan pengemasan jasa.

4. Sumber-sumber publik. Sumber ini mencangkup publisitas, seperti artikel tentang perusahaan di surat kabar dan perangkingan jasa independen di majalah (media) khusus.

5. Sumber-sumber pengalaman. Informasi jenis ini merujuk kepada penanganan, percobaan atau dengan cara bertanya kepada konsumen lain yang sudah pernah mengalami atau mencoba jasa yang dimaksud.

Berdasarkan pendapat diatas dapat dikatakan bahwa konsumen atau pembeli akan melakukan usaha untuk mencari informasi mengenai barang atau jasa yang diinginkannya.

\section{Evaluasi Alternatif}

Dalam proses evaluasi keputusan terdapat model yang terbaru yang memandang proses evaluasi konsumen sebagai proses yang berorientasi kognitif, yaitu mereka menganggap konsumen membentuk penilaian atas produk atau jasa terutama berdasarkan kesadaran dan rasio. Ada beberapa konsep dasar dalam memahami proses evaluasi konsumen yaitu konsumen 
Syarifuddin Arief, Pengaruh Bauran Pemasaran Terhadap Keputusan Konsumen Perawatan Kulit Pada Klinik Kecantikan DRM Skin Clinic Di Makassar $\mid \mathbf{1 1 7}$

berusaha memenuhi suatu kebutuhan kemudian konsumen mencari manfaat tertentu dari solusi produk atau jasa tersebut, dan yang terakhir konsumen memandang setiap produk sebagai sekumpulan atribut dengan kemampuan yang berdeba-beda dalam memberikan manfaat yang dicari untuk memuaskan kebutuhan ini. Konsumen mengevaluasi pilihan berkenaan dengan manfaat yang diharapkan dan menyempitkan pilihan hingga alternatif yang dipilih (Kotler, 2005:172).

Sedangkan menurut Yazid (1999:52), konsumen jasa mengevaluasi alternatif-alternatif berdasarkan logika dasar yang dijelaskan dalam urutan sebagai berikut :

1. Konsumen mempunyai informasi tentang sejumlah organisasi yang menawarkan jasa yang sama.

2. Konsumen menerima bahwa paling sedikit beberapa organisasi yang menawarkan jasa yang sama tersebut merupakan alternatif-alternatif yang bisa dipilih dan mampu memuaskan kebutuhan.

3. Setiap organisasi itu mempunyai sejumlah atribut yang bisa dibedakan.

4. Atribut-atribut tersebut relevan bagi konsumen dan konsumen menerima bahwa setiap organisasi berbeda dalam kompleksivitas dan prosesnya.

5. Organisasi jasa yang menawarkan paling banyak atribut jasa yang diinginkan dalam jumlah yang dikehendaki akan merupakan organisasi jasa yang paling disukai.

6. Organisasi jasa yang paling disukai konsumen adalah organisasi jasa kepada siapa konsumen akan membeli jasanya.

Atribut-atribut jasa yang bisa ditonjolkan kepada konsumen, menurut para ahli mencangkup :

1. Pencarian kualitas (search quality), yaitu atribut yang dapat ditentukan

2. Konsumen sebelum membeli suatu barang.

3. Pengalaman kualitas (experience quality), yaitu atribut yang dapat diketahui setelah pembelian atau selama konsumsi berlangsung.

4. Bukti kualitas (evidence quality), adalah karakteristik yang mungkin sulit bagi konsumen untuk mengevaluasinya meskipun mereka telah membeli maupun telah mengkonsumsinya.

Berdasar pendapat diatas dalam hal ini dapat dikatakan bahwa pada tahap ini konsumen mengevaluasi alternatif-alternatif produk atau jasa yang ada sebelum melakukan analisis dan melakukan keputusan pembelian.

\section{Keputusan Pembelian}

Setelah evaluasi alternatif, menurut Kotler (2005:174), konsumen mungkin akan membentuk niat untuk membeli produk atau jasa yang paling disukai namun sebelum melakukan keputusan pembelian, ada dua faktor yang berada diantara niat pembelian dan keputusan pembelian yaitu pendirian orang lain yaitu berdasar pengaruh orang lain sedangkan faktor yang kedua adalah faktor situasi yang tidak diantisipasi. Faktor yang kedua ini dapat muncul dan mengubah niat pembelian. Dalam menjalankan niat pembelian, konsumen dapat membuat lima sub-keputusan pembelian yaitu keputusan atas merek, keputusan pemasok, keputusan kuantitas, keputusan waktu, dan keputusan metode pembayaran. 
118|Ad'ministrare, Vol. 3 No. 2, 2016

Berdasarkan pendapat diatas, dapat pula dikatakan bahwa konsumen akan melakukan keputusan pembelian apabila konsumen telah menganalisis evaluasi alternatif yang ada dan memutuskan untuk melakukan pembelian.

\section{Perilaku Pasca Pembelian}

Menurut Kotler (2005:175), konsumen yang telah membeli produk atau jasa akan mengalami tingkat kepuasan atau tidak kepuasan tertentu. Bagi pihak pemasar harus memantau perilaku pembeli dalam keputusannya pasca pembelian, kemudian tindakan pasca pembelian, dan pemakaian dan pembuangan pasca pembelian. Konsumen mengevaluasi apakah alternatif yang dipilih memenuhi kebutuhan dan harapan segera sesudah digunakan. Pada perilaku konsumen produk lebih menghasilkan kepuasan dan ketidakpuasan sedangkan pada konsumen jasa perilaku pasca pembelian ini akan mementingkan pemenuhan akan harapan konsumen, ketepatan waktu, aktivitas pekerjaan, kecepatan tanggapan, dan unjuk kerja.

\section{METODE PENELITIAN}

Penelitian ini merupakan penelitian penjelasan atau explanatory research, yaitu penelitian yang menjelaskan hubungan kausal antara variabel-variabel melalui pengujian hipotesa pada data yang sama. Sedangkan berdasarkan tingkat eksplanasi atau penjelasan, penelitian yang digunakan adalah penelitian assosiatif, menurut Sugiyono (2004:11) yaitu "penelitian yang bertujuan untuk mengetahui hubungan atau pengaruh antara dua variabel atau lebih". Penelitian ini dilakukan pada DRM Skin Clinic yang berlokasi di Jalan A.P. Pettarani, Kompleks Pettarani Center Blok A8 Makassar. Waktu penelitian berlangsung dari bulan Desember 2012 sampai Februari 2013. Populasi dalam penelitian ini adalah sebanyak 2.500 orang. Dalam penelitian ini populasinya adalah jumlah seluruh pelanggan DRM Skin Clinic yang diambil dengan teknik Simple random sampling dengan sampel sebanyak 96 responden. Teknik pengumpulan data yang dipergunakan oleh peneliti melalui penyebaran angket atau kuisioner. Kuisioner yaitu daftar pertanyaan yang diajukan kepada responden yang diharapkan ada jawaban yang tepat dalam pengumpulan data. Adapun analisis data yang digunakan, yaitu: 1) Uji Validitas dan Reliabilitas, 2) Uji Asumsi Klasik seperti: a) Uji Multikolinearitas, b) Uji autokorelasi, c) Normalitas (Normality), dan d) Uji Heteroskedastisitas, 3) regresi berganda.

\section{HASIL DAN PEMBAHASAN}

\section{Hasil Uji Validitas Dan Reliabilitas}

Uji validitas dan reliabilitas terhadap kuesioner atau instrumen penelitian dimaksudkan untuk menguji kelayakan secara psikometri suatu kuesioner. Kuesioner yang valid dan reliabel akan menjamin data yang diperoleh tidak mengalami bias yang berarti. Hasil uji reliabilitas menunjukkan bawah kuesioner ini memiliki koefisien reliabilitas Alpha-Cronbach sebesar 0,971. Oleh karena nilai tersebut lebih besar dari 0,6, maka disimpulkan bahwa kuesioner variabel- 
Syarifuddin Arief, Pengaruh Bauran Pemasaran Terhadap Keputusan Konsumen Perawatan Kulit Pada Klinik Kecantikan DRM Skin Clinic Di Makassar|119

variabel yang digunakan dalam penelitian ini reliabel. Hasil uji validitas dan reliabilitas dapat dilihat pada tabel berikut:

Tabel 2. Hasil Uji Validitas dan Reliabilitas

\begin{tabular}{|c|c|c|c|c|}
\hline Variabel & Indikator & R hitung & $R$ tabel & Ket. \\
\hline \multirow[t]{3}{*}{ Produk (X1) } & X1.1 & 0,712 & 0,198 & Valid \\
\hline & $\mathrm{X} 1.2$ & 0,677 & 0,198 & Valid \\
\hline & $\mathrm{X} 1.3$ & 0,500 & 0,198 & Valid \\
\hline \multirow[t]{5}{*}{ Harga (X2) } & $\mathrm{X} 2.1$ & 0,667 & 0,198 & Valid \\
\hline & $\mathrm{X} 2.2$ & 0,789 & 0,198 & Valid \\
\hline & $\mathrm{X} 2.3$ & 0,675 & 0,198 & Valid \\
\hline & $\mathrm{X} 2.4$ & 0,605 & 0,198 & Valid \\
\hline & $\mathrm{X} 2.5$ & 0,546 & 0,198 & Valid \\
\hline \multirow[t]{5}{*}{ Lokasi (X3) } & $\mathrm{X} 3.1$ & 0,761 & 0,198 & Valid \\
\hline & X3.2 & 0,741 & 0,198 & Valid \\
\hline & X3.3 & 0,695 & 0,198 & Valid \\
\hline & X3.4 & 0,642 & 0,198 & Valid \\
\hline & $\mathrm{X} 3.5$ & 0,728 & 0,198 & Valid \\
\hline \multirow[t]{5}{*}{ Promosi $(\mathrm{X} 4)$} & $\mathrm{X} 4.1$ & 0,569 & 0,198 & Valid \\
\hline & $\mathrm{X} 4.2$ & 0,581 & 0,198 & Valid \\
\hline & $\mathrm{X} 4.3$ & 0,450 & 0,198 & Valid \\
\hline & $\mathrm{X} 4.4$ & 0,763 & 0,198 & Valid \\
\hline & $\mathrm{X} 4.5$ & 0,649 & 0,198 & Valid \\
\hline \multirow[t]{5}{*}{ Partisipan (X5) } & $\mathrm{X} 5.1$ & 0,788 & 0,198 & Valid \\
\hline & $\mathrm{X} 5.2$ & 0,571 & 0,198 & Valid \\
\hline & $\mathrm{X} 5.3$ & 0,750 & 0,198 & Valid \\
\hline & $\mathrm{X} 5.4$ & 0,688 & 0,198 & Valid \\
\hline & $\mathrm{X} 5.5$ & 0,765 & 0,198 & Valid \\
\hline \multirow[t]{5}{*}{ Proses (X6) } & X6.1 & 0,475 & 0,198 & Valid \\
\hline & $\mathrm{X} 6.2$ & 0,644 & 0,198 & Valid \\
\hline & X6.3 & 0,786 & 0,198 & Valid \\
\hline & X6.4 & 0,760 & 0,198 & Valid \\
\hline & X6.5 & 0,810 & 0,198 & Valid \\
\hline \multirow[t]{6}{*}{ Lingkungan Fisik (X7) } & $\mathrm{X} 7.1$ & 0,764 & 0,198 & Valid \\
\hline & $\mathrm{X} 7.2$ & 0,610 & 0,198 & Valid \\
\hline & $\mathrm{X} 7.3$ & 0,695 & 0,198 & Valid \\
\hline & $\mathrm{X} 7.4$ & 0,552 & 0,198 & Valid \\
\hline & $\mathrm{X} 7.5$ & 0,819 & 0,198 & Valid \\
\hline & $\mathrm{X} 7.6$ & 0,475 & 0,198 & Valid \\
\hline
\end{tabular}




\begin{tabular}{|l|c|c|c|c|}
\hline & X7.7 & 0,619 & 0,198 & Valid \\
\cline { 2 - 5 } & X7.8 & 0,672 & 0,198 & Valid \\
\hline \multirow{3}{*}{ Kinerja (Y) } & Y.1 & 0,685 & 0,198 & Valid \\
\cline { 2 - 5 } & Y.2 & 0,706 & 0,198 & Valid \\
\cline { 2 - 5 } & Y.3 & 0,635 & 0,198 & Valid \\
\hline \multicolumn{2}{|c}{ Reliabilitas Alpha-Cronbach $=0,971$} \\
\hline
\end{tabular}

Sumber: Data primer diolah, 2013

Kesimpulan dari hasil uji validitas dan reliabilitas terhadap variabel-variabel penelitian adalah kuesioner ini secara psikometrik layak digunakan sebagai alat/instrumen pengumpul data.

\section{Uji Persyaratan Analisis (Uji Asumsi Klasik)}

Analisis yang digunakan untuk menguji hipotesis dalam penelitian ini adalah analisis regresi linier berganda. Penggunaan analisis regresi linier berganda memerlukan asumsi yang harus dipenuhi, yaitu (1) data yang diperoleh dari sampel yang digunakan dalam penelitian harus berdistribusi normal, (2) independensi variabel, yakni tidak adanya saling ketergantungan pada masing-masing variabel penelitian (saling bebas), dan (3) varian dari residual tidak sama untuk satu pengamatan ke pengamatan yang lain. Sesuai dengan asumsi tersebut maka uji normalitas, uji multikolinieritas, dan uji heterokedastisitas harus dilakukan terlebih dahulu. Hasil uji persyaratan analisis ini disajikan pada lampiran

\section{Uji Normalitas.}

Uji normalitas data dimaksudkan sebagai persyaratan dalam penggunaan statistik parametrik, sekaligus untuk mengetahui data yang terkumpul dari responden berdistribusi normal atau tidak. Uji normalitas bisa dilihat pada nilai Kolmogorov-Smirnov. Data dianggap berdistribusi normal jika nilai probabilitas $>0,05$ dan sebaliknya data dianggap tidak berdistribusi normal jika nilai probabilitas $<0,05$.

Tabel 3 Hasil Uji Normalitas

Tests of Normality

\begin{tabular}{|l|r|r|r|r|r|r|}
\hline & \multicolumn{3}{|c|}{ Kolmogorov-Smirnov ${ }^{\mathrm{a}}$} & \multicolumn{3}{c|}{ Shapiro-Wilk } \\
\cline { 2 - 7 } & \multicolumn{1}{|c|}{ Statistic } & \multicolumn{1}{c|}{$\mathrm{df}$} & \multicolumn{1}{c|}{ Sig. } & \multicolumn{1}{c|}{ Statistic } & \multicolumn{1}{c|}{ df } & \multicolumn{1}{c|}{ Sig. } \\
\hline X1 & 1.186 & 96 & .265 & 1.936 & 96 & .145 \\
X2 & 1.194 & 96 & .538 & 1.951 & 96 & .123 \\
X3 & 1.192 & 96 & .616 & 1.930 & 96 & .115 \\
X4 & 1.143 & 96 & .737 & 1.945 & 96 & .555 \\
X5 & 1.167 & 96 & .418 & 1.929 & 96 & .542 \\
X6 & 1.225 & 96 & .570 & 1.931 & 96 & .133 \\
X7 & 1.191 & 96 & .893 & 1.944 & 96 & .433 \\
Y & 1.214 & 96 & .829 & 1.890 & 96 & .287 \\
\hline
\end{tabular}

a. Lilliefors Signific ance Correction 
Syarifuddin Arief, Pengaruh Bauran Pemasaran Terhadap Keputusan Konsumen Perawatan Kulit Pada Klinik Kecantikan DRM Skin Clinic Di Makassar|121

Dari tabel 3 terlihat bahwa semua variabel memiliki nilai probabilitas $>0.05$ sehingga dapat disimpulkan bahwa semua variabel memiliki data yang dianggap berdistribusi normal.

\section{Uji Multikolinieritas}

Uji multikolinieritas dilakukan dengan mengacu pada pandangan Ghozali (2001: 59) yang menyatakan bahwa gejala multikolinieritas dapat dilihat dari nilai tolerance dan variance inflation factor $(V I F)$. Suatu variabel bebas yang memiliki nilai VIF lebih kecil dari 10 dapat disimpulkan tidak terjadi multikolinieritas. Hasil perhitungan uji multikolinieritas terlihat pada tabel 4.

\section{Tabel 4 Rangkuman hasil uji multikolinieritas}

\begin{tabular}{|c|c|c|c|}
\hline \multicolumn{4}{|c|}{ Coefficients } \\
\hline \multirow{2}{*}{\multicolumn{2}{|c|}{ Model }} & \multicolumn{2}{|c|}{ Collinearity Statistics } \\
\hline & & Tolerance & VIF \\
\hline \multirow[t]{7}{*}{1} & $\mathrm{X} 1$ & .328 & 3.051 \\
\hline & $\times 2$ & .159 & 6.308 \\
\hline & X3 & .213 & 4.692 \\
\hline & $\times 4$ & .228 & 4.388 \\
\hline & $\times 5$ & .188 & 5.333 \\
\hline & $\times 6$ & .151 & 6.611 \\
\hline & $\times 7$ & .296 & 3.374 \\
\hline
\end{tabular}

a. Dependent Variable: $Y$

Sumber: data primer diolah, 2013

Dari tabel rangkuman hasil uji multikolinieritas di atas, terlihat bahwa ketujuh variabel mempunyai nilai $V I F<10$ sehingga dapat disimpulkan bahwa tidak terjadi multikolinieritas antara ketujuh variabel bebas.

\section{Uji Heterokesdastisitas.}

Uji heterokedastisitas adalah asumsi dalam regresi dimana varian dari residual tidak sama untuk satu pengamatan ke pengamatan yang lain. Salah satu yang harus dipenuhi adalah bahwa varians dari residual dari satu pengamatan ke pengamatan yang lain tidak memiliki pola tertentu. Pola yang tidak sama ini ditunjukkan dengan nilai yang tidak sama antara satu varians dari residual. Hasil uji heterokedastisitas dengan program SPSS 17 dapat dilihat pada gambar 2. 


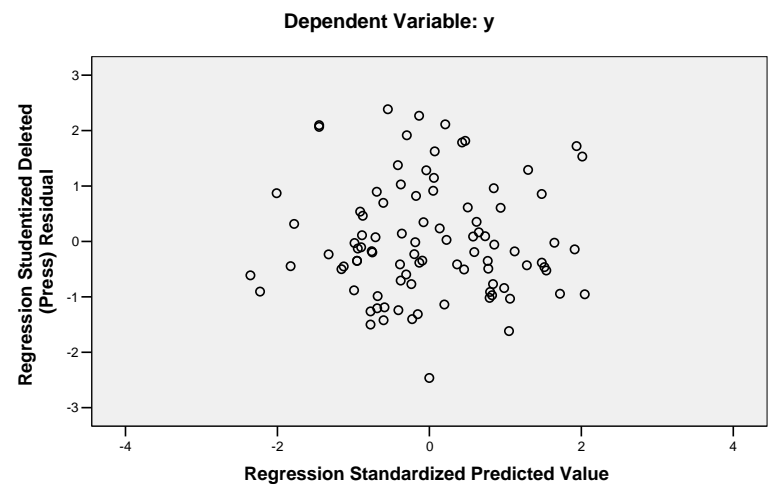

Gambar. 2. Uji Heterokedastisitas

Berdasarkan Gambar di atas, terlihat sebaran titik-titik yang acak baik diatas maupun dibawah angka 0 dari sumbu $Y$ dan tidak membentuk pola tertentu, dan dapat disimpulkan tidak terjadi heterokesdastisitas dalam model regresi.

\section{Analisis Pengujian Hipotesis Penelitian}

Untuk mengetahui apakah ketujuh variabel yaitu produk, harga, lokasi, promosi, partisipan, proses, dan lingkungan fisik berpengaruh positif dan signifikan terhadap keputusan konsumen perawatan kulit pada klinik kecantikan DRM Skin Clinic maka digunakan model analisis statistik yaitu regresi linier berganda dengan bantuan program statistik SPSS 17. Penelitian ini telah memenuhi syarat untuk menggunakan pengujian regresi berganda karena telah dilakukan uji validitas dan asumsi klasik, sehingga analisis selanjutnya dapat digunakan.

\section{Analisis Regresi Linier Berganda}

Untuk mengetahui pengaruh variabel bauran pemasaran (produk, harga, lokasi, promosi, partisipan, proses, dan lingkungan fisik) terhadap keputusan konsumen perawatan kulit pada klinik kecantikan DRM Skin Clinic maka digunakan analisis regresi linier berganda, dimana variabel bebasnya adalah produk (X1), harga (X2), promosi (X3), lokasi (X4), partisipan (X5), proses (X6), dan lingkungan fisik (X7) sedangkan variabel terikatnya adalah keputusan pembelian konsumen (Y). Berikut hasil uji regresi yang dilakukan. 
Syarifuddin Arief, Pengaruh Bauran Pemasaran Terhadap Keputusan Konsumen Perawatan Kulit Pada Klinik Kecantikan DRM Skin Clinic Di Makassar|123

Tabel 5. Hasil Uji Regresi Linier Berganda

\begin{tabular}{|c|c|c|c|c|}
\hline Variabel & Koefisien Regresi (B) & T hitung & Nilai $\mathbf{P}$ & Keterangan \\
\hline Produk $(\mathrm{X} 1)$ & 0,142 & 2,138 & 0,035 & Signifikan \\
\hline Harga (X2) & $-0,067$ & $-0,600$ & 0,550 & Tidak Signifikan \\
\hline Lokasi (X3) & 0,173 & 2,057 & 0,043 & Signifikan \\
\hline Promosi (X4) & 0,304 & 2,900 & 0,005 & Signifikan \\
\hline Partisipan (X5) & 0,020 & 0,223 & 0,828 & Tidak Signifikan \\
\hline Proses $(\mathrm{X} 6)$ & 0,224 & 2,015 & 0,047 & Signifikan \\
\hline $\begin{array}{l}\text { Lingkungan fisik } \\
\text { (X7) }\end{array}$ & 0,156 & 2,036 & 0,045 & Signifikan \\
\hline \multicolumn{5}{|c|}{ Konstanta $=0,428$} \\
\hline \multicolumn{5}{|c|}{ F hitung $=57,242, \mathrm{P}=0,000$} \\
\hline \multicolumn{5}{|c|}{$\mathrm{F}$ Tabel $=2,115, \mathrm{t}$ tabel $=1,987$} \\
\hline \multicolumn{5}{|l|}{$\mathrm{R}=0,905, \mathrm{R}^{2}=0,820$} \\
\hline
\end{tabular}

Sumber: Data primer diolah, 2013

berikut:

Berdasarkan hasil uji regresi berganda yang dilakukan, dapat dibuat persamaan sebagai

$\mathrm{Y}=0,428+0,142 \mathrm{X} 1-0,067 \mathrm{X} 2+0,173 \mathrm{X} 3+0,304 \mathrm{X} 4+0,020 \mathrm{X} 5+0,224 \mathrm{X} 6+0,156 \mathrm{X} 7$

Dari persamaan yang terbentuk di atas dapat dijelaskan interpretasinya sebagai berikut:

1. $b_{0}$ (konstanta) $=0,428$ artinya apabila variabel bauran pemasaran (produk, harga, promosi, lokasi, partisipan, proses, dan lingkungan fisik) dalam keadaan konstan, maka keputusan perawatan kulit konsumen pada klinik kecantikan DRM Skin Clinic adalah sebesar 0,428 satuan.

2. $b_{1}=0,142$ merupakan koefisien regresi yang menunjukkan bahwa apabila variabel produk bertambah 1 satuan, maka keputusan perawatan kulit konsumen akan meningkat sebesar 0,142 satuan, dengan asumsi bahwa variabel-variabel lain berada dalam keadaan konstan.

3. $b_{2}=-0,067$ merupakan koefisien regresi yang menunjukkan bahwa apabila variabel harga bertambah 1 satuan, maka keputusan perawatan kulit konsumen akan menurun sebesar 0,067 satuan, dengan asumsi bahwa variabel-variabel lain berada dalam keadaan konstan.

4. $\mathrm{b}_{3}=0,173$ merupakan koefisien regresi yang menunjukkan bahwa apabila variabel tempat bertambah 1 satuan, maka keputusan perawatan kulit konsumen akan meningkat sebesar 0,173 satuan, dengan asumsi bahwa variabel-variabel lain berada dalam keadaan konstan.

5. $b_{4}=0,304$ merupakan koefisien regresi yang menunjukkan bahwa apabila variabel promosi bertambah 1 satuan, maka keputusan perawatan kulit konsumen akan meningkat sebesar 0,304 satuan, dengan asumsi bahwa variabel-variabel lain berada dalam keadaan konstan.

6. $b_{5}=0,020$ merupakan koefisien regresi yang menunjukkan bahwa apabila variabel partisipan bertambah 1 satuan, maka keputusan perawatan kulit konsumen akan meningkat sebesar 0,020 satuan, dengan asumsi bahwa variabel-variabel lain berada dalam keadaan konstan. 
7. $\mathrm{b}_{6}=0,224$ merupakan koefisien regresi yang menunjukkan bahwa apabila variabel proses bertambah 1 satuan, maka keputusan perawatan kulit konsumen akan meningkat sebesar 0,224 satuan, dengan asumsi bahwa variabel-variabel lain berada dalam keadaan konstan.

8. $\mathrm{b}_{7}=0,156$ merupakan koefisien regresi yang menunjukkan bahwa apabila variabel lingkungan fisik bertambah 1 satuan, maka keputusan perawatan kulit konsumen akan meningkat sebesar 0,156 satuan, dengan asumsi bahwa variabel-variabel lain berada dalam keadaan konstan.

\section{Uji F (Uji Simultan)}

Uji F dilakukan untuk mengetahui pengaruh variabel bauran pemasaran (produk, harga, lokasi, promosi, partisipan, proses, dan lingkungan fisik) terhadap keputusan konsumen perawatan kulit pada klinik kecantikan DRM Skin Clinic secara simultan. Uji F dilakukan dengan membandingkan nilai $\mathrm{F}$ hitung dengan $\mathrm{F}$ tabel. Apabila $\mathrm{F}$ hitung $>\mathrm{F}$ tabel, maka dikatakan pengaruhnya signifikan, dan apabila $\mathrm{F}$ hitung $<\mathrm{F}$ tabel, maka dikatakan pengaruhnya tidak signifikan. Dari tabel di atas diperoleh F hitung lebih besar dari F tabel, yakni 57,242 > 2,115. Jadi, bauran pemasaran (produk, harga, lokasi, promosi, partisipan, proses, dan lingkungan fisik) mempunyai pengaruh yang positif dan signifikan terhadap keputusan konsumen perawatan kulit pada klinik kecantikan DRM Skin Clinic secara simultan.

\section{Uji T (Uji Parsial)}

Uji t dilakukan untuk mengetahui pengaruh variabel bauran pemasaran (produk, harga, lokasi, promosi, partisipan, proses, dan lingkungan fisik) terhadap keputusan konsumen perawatan kulit pada klinik kecantikan DRM Skin Clinic secara parsial. Uji t dilakukan dengan membandingkan nilai $\mathrm{t}$ hitung dengan $\mathrm{t}$ tabel. Apabila $\mathrm{t}$ hitung $>\mathrm{t}$ tabel, maka dikatakan pengaruhnya signifikan, dan apabila $t$ hitung $<\mathrm{t}$ tabel, maka dikatakan pengaruhnya tidak signifikan. Dari tabel di atas diperoleh t hitung untuk variabel produk (X1) lebih besar dari t tabel, yakni $2,138>1,987$.

1. Variabel produk (X1) mempunyai pengaruh yang positif dan signifikan terhadap keputusan konsumen perawatan kulit pada klinik kecantikan DRM Skin Clinic secara parsial.

2. T hitung untuk variabel harga (X2) lebih kecil dari t tabel, yakni $-0,600<1$,987. Jadi, variabel harga (X2) mempunyai pengaruh yang negatif dan tidak signifikan terhadap keputusan konsumen perawatan kulit pada klinik kecantikan DRM Skin Clinic secara parsial.

3. T hitung untuk variabel lokasi (X3) lebih besar dari t tabel, yakni 2,057 > 1,987. Jadi, variabel lokasi (X3) mempunyai pengaruh yang positif dan signifikan terhadap keputusan konsumen perawatan kulit pada klinik kecantikan DRM Skin Clinic secara parsial.

4. T hitung untuk variabel promosi (X4) lebih besar dari t tabel, yakni 2,900 > 1,987. Jadi, variabel promosi (X4) mempunyai pengaruh yang positif dan signifikan terhadap 
Syarifuddin Arief, Pengaruh Bauran Pemasaran Terhadap Keputusan Konsumen Perawatan Kulit Pada Klinik Kecantikan DRM Skin Clinic Di Makassar|125

keputusan konsumen perawatan kulit pada klinik kecantikan DRM Skin Clinic secara parsial.

5. T hitung untuk variabel partisipan (X5) lebih kecil dari t tabel, yakni 0,223 < 1,987. Jadi, variabel partisipan (X5) mempunyai pengaruh yang positif dan tidak signifikan terhadap keputusan konsumen perawatan kulit pada klinik kecantikan DRM Skin Clinic secara parsial.

6. T hitung untuk variabel proses (X6) lebih besar dari t tabel, yakni 2,015 > 1,987. Jadi, variabel proses (X6) mempunyai pengaruh yang positif dan signifikan terhadap keputusan konsumen perawatan kulit pada klinik kecantikan DRM Skin Clinic secara parsial.

7. Thitung untuk variabel lingkungan fisik (X7) lebih besar dari t tabel, yakni 2,036 > 1,987. Jadi, variabel lingkungan fisik (X7) mempunyai pengaruh yang positif dan signifikan terhadap keputusan konsumen perawatan kulit pada klinik kecantikan DRM Skin Clinic secara parsial.

Dari hasil uji t tersebut di atas dapat disimpulkan bahwa variabel yang paling dominan pengaruhnya terhadap keputusan konsumen perawatan kulit pada klinik kecantikan DRM Skin Clinic adalah variabel promosi (X4) dengan nilai t hitung terbesar $(2,900)$ dan nilai signifikansi terkecil $(0,005)$.

\section{Uji Korelasi}

Untuk mengetahui keeratan hubungan antara variabel bauran pemasaran (produk, harga, lokasi, promosi, partisipan, proses, dan lingkungan fisik) dengan keputusan konsumen perawatan kulit pada klinik kecantikan DRM Skin Clinic maka dilakukan uji korelasi. Dari hasil uji korelasi yang dilakukan didapat nilai korelasi (R) sebesar 0,905 yang signifikan pada $\alpha=0,05$. Hal ini menunjukkan bahwa ada hubungan yang sangat kuat dan signifikan antara variabel bauran pemasaran (produk, harga, lokasi, promosi, partisipan, proses, dan lingkungan fisik) dengan keputusan konsumen perawatan kulit pada klinik kecantikan DRM Skin Clinic.

\section{Koefisien Determinasi}

Koefisien determinasi $\left(\mathrm{R}^{2}\right)$ digunakan untuk mengetahui seberapa besar kontribusi variabel-variabel bebas dalam menjelaskan variasi variabel terikat. Dari tabel di atas diperoleh koefisien determinasi $\left(\mathrm{R}^{2}\right)$ sebesar $0,820(82 \%)$. Ini berarti bahwa variasi terikat keputusan konsumen perawatan kulit (Y) dapat dijelaskan oleh variabel produk (X1), harga (X2), lokasi (X3), promosi (X4), partisipan (X5), proses (X6), dan lingkungan fisik (X7) sebesar 82\%, sedangkan sisanya $18 \%$ dijelaskan oleh variabel-variabel lain diluar variabel yang diteliti. 
126|Ad'ministrare, Vol. 3 No. 2, 2016

\section{Pembahasan}

Penelitian ini menunjukkan bahwa secara simultan tujuh variabel bebas yaitu produk, harga, lokasi, promosi, partisipan, proses, dan lingkungan fisik berpengaruh positif dan signifikan terhadap keputusan konsumen perawatan kulit pada klinik kecantikan DRM Skin Clinic. Sedangkan secara parsial, variabel bebas yang berpengaruh positif dan signifikan terhadap keputusan konsumen perawatan kulit pada klinik kecantikan DRM Skin Clinic adalah produk, lokasi, promosi, proses, dan lingkungan fisik. Variabel harga berpengaruh negatif namun tidak signifikan terhadap keputusan konsumen perawatan kulit pada klinik kecantikan DRM Skin Clinic, sedangkan variabel partisipan berpengaruh positif namun tidak signifikan terhadap keputusan konsumen perawatan kulit pada klinik kecantikan DRM Skin Clinic. Untuk membahas pengaruh secara parsial masing-masing variabel bebas terhadap variabel terikat, maka berikut ini akan diuraikan satu persatu:

\section{Pengaruh Produk Terhadap Keputusan Konsumen Dalam Pembelian Produk}

Berdasarkan hasil perhitungan analisis regresi linear berganda dengan pengujian secara parsial diketahui bahwa variabel produk $\left(\mathrm{X}_{1}\right)$ diperoleh koefisien sebesar 0,142, t-hitung 2,127 dan nilai signifikansi 0,035 yang berarti jika terdapat peningkatan terhadap produk 1 satuan maka akan meningkatkan keputusan konsumen perawatan kulit pada klinik kecantikan DRM Skin Clinic sebesar 0,142 satuan. Dengan kata lain setiap ada perubahan atau penambahan nilai produk akan meningkatkan keputusan konsumen perawatan kulit pada klinik kecantikan DRM Skin Clinic.

Hal ini sejalan dengan pendapat Payne (2000:157) bahwa produk jasa merupakan rangkaian pemuasan nilai yang kompleks. Orang membeli jasa untuk memecahkan masalah mereka dan memberikan nilai dalam kaitannya dengan kemampuan jasa yang dipersepsikan untuk memecahkan masalah tersebut. Sebenarnya pelanggan tidak membeli barang atau jasa tetapi mereka membeli manfaat spesifik dan nilai dari penawaran total. Disarankan bahwa penawaran dapat dilihat pada beberapa level, yaitu: produk inti atau generik, produk yang diharapkan, produk yang diperluas (augmented product), dan produk potensial. Dengan demikian, produk jasa merupakan rangkaian pemuasan nilai yang kompleks. Orang membeli jasa untuk memecahkan masalah dan mereka melekatkan nilai pada jasa-jasa dalam kaitannya dengan kemampuan jasa yang dipersepsikan untuk memecahkan masalah tersebut.

Hal ini sejalan pula dengan temuan penelitian dari Ginting (2003), Wasis (2007), Kurniawan (2009), Sukotjo dan Radix (2010), dan Irwinda (2011) yang menyatakan bahwa produk berpengaruh signifikan terhadap keputusan pembelian konsumen.

\section{Pengaruh Harga Terhadap Keputusan Konsumen Dalam Pembelian Produk}

Berdasarkan hasil perhitungan analisis regresi linear berganda dengan pengujian secara parsial diketahui bahwa variabel harga $\left(\mathrm{X}_{2}\right)$ diperoleh koefisien sebesar -0,067, t-hitung -0,600 dan nilai signifikansi 0,550 yang berarti jika terdapat peningkatan terhadap harga 1 satuan maka akan mengurangi keputusan konsumen perawatan kulit pada klinik kecantikan DRM Skin Clinic 
sebesar 0,067 satuan. Dengan kata lain setiap ada perubahan atau penambahan harga akan mengurangi keputusan konsumen perawatan kulit pada klinik kecantikan DRM Skin Clinic.

Hal ini sejalan dengan pendapat Kotler (1997:339) bahwa harga adalah jumlah uang yang ditagihkan untuk suatu produk atau jasa, jumlah nilai yang dipertukarkan konsumen untuk manfaat yang dimiliki dengan menggunakan produk atau menggunakan produk atau jasa. Sedangkan menurut Payne (2000:171) harga memainkan bagian yang sangat penting dalam bauran pemasaran jasa, karena penetapan harga memberikan penghasilan bagi bisnis. Tujuan dari penetapan harga meliputi kelangsungan hidup, maksimalisasi keuntungan, maksimalisasi penjualan, gengsi (prestise), dan ROI (retrun on investment).

Dengan demikian harga merupakan alat yang digunakan oleh pemasar untuk memberikan penilaian terhadap suatu produk. Peranan harga sangat penting terutama pada keadaan persaingan yang semakin tajam dan perkembangan permintaan yang terbatas. Di dalam keadaan persaingan yang semakin tajam dewasa ini, terutama sangat terasa dalam pasar pembeli (buyers market), peranan harga sangat penting terutama untuk menjaga dan meningkatkan posisi perusahaan di pasar, yang tercermin dalam market share perusahaan, di samping untuk meningkatkan penjualan dan keuntungan perusahaan, dengan kata lain, penetapan harga mempengaruhi kemampuan bersaing perusahaan dan kemampuan perusahaan dalam mempengaruhi konsumen.

Harga adalah segala sesuatu yang diberikan oleh pelanggan untuk mendapatkan keunggulan yang ditawarkan oleh bauran pemasaran perusahaan. Harga dapat menunjukkan kualitas merek dari suatu produk, dimana konsumen mempunyai anggapan bahwa harga yang mahal biasanya mempunyai kualitas yang baik. Pada umumnya harga mempunyai pengaruh yang positif dengan kualitas, semakin tinggi harga maka akan semakin tinggi kualitas. Konsumen mempunyai anggapan adanya hubungan yang positif antara harga dan kualitas suatu produk, maka mereka akan membandingkan antara produk yang satu dengan produk yang lainnya, dan barulah konsumen mengambil keputusan untuk membeli suatu produk (Kotler, 1997). Namun dalam penelitian ini harga tidak berpengaruh signifikan terhadap keputusan pembelian konsumen karena responden dalam penelitian ini menganggap bahwa harga bukanlah faktor yang mempengaruhi keputusan pembelian mereka.

\section{Pengaruh Lokasi Terhadap Keputusan Konsumen Dalam Pembelian Produk}

Berdasarkan hasil perhitungan analisis regresi linear berganda dengan pengujian secara parsial diketahui bahwa variabel lokasi $\left(\mathrm{X}_{3}\right)$ diperoleh koefisien sebesar 0,173, t-hitung 2,057 dan nilai signifikansi 0,043 yang berarti jika terdapat peningkatan terhadap lokasi 1 satuan maka akan meningkatkan keputusan konsumen perawatan kulit pada klinik kecantikan DRM Skin Clinic sebesar 0,173 satuan. Dengan kata lain setiap ada perubahan atau penambahan nilai lokasi akan meningkatkan keputusan konsumen perawatan kulit pada klinik kecantikan DRM Skin Clinic.

Hal ini sejalan dengan pendapat Kotler (1997:82) dan Payne (2000:181) bahwa lokasi berkenaan dengan keputusan perusahaan mengenai dimana operasi dan stafnya akan ditempatkan. Pentingnya lokasi untuk jasa tergantung pada jenis dan tingkat interaksi yang terlibat. Apabila pelanggan harus mendatangi penyedia jasa, lokasi usaha menjadi sangat penting, lokasi mungkin merupakan salah satu alasan utama untuk langganan. Sedangkan jika penyedia jasa dapat 
mendatangi pelanggan, lokasi tempat usaha menjadi kurang penting apabila perusahaan cukup dekat dengan pelanggan yang bakal menerima jasa yang berkualitas bagus.

Hal ini sejalan pula dengan temuan penelitian dari Ginting (2003), Wasis (2007), Kurniawan (2009), Sukotjo dan Radix (2010), dan Irwinda (2011) yang menyatakan bahwa lokasi berpengaruh signifikan terhadap keputusan pembelian konsumen.

\section{Pengaruh Promosi Terhadap Keputusan Konsumen Dalam Pembelian Produk}

Berdasarkan hasil perhitungan analisis regresi linear berganda dengan pengujian secara parsial diketahui bahwa variabel promosi $\left(\mathrm{X}_{4}\right)$ diperoleh koefisien sebesar 0,304, t-hitung 2,900 dan nilai signifikansi 0,005 yang berarti jika terdapat peningkatan terhadap promosi 1 satuan maka akan meningkatkan keputusan konsumen perawatan kulit pada klinik kecantikan DRM Skin Clinic sebesar 0,304 satuan. Dengan kata lain setiap ada perubahan atau penambahan nilai promosi akan meningkatkan keputusan konsumen perawatan kulit pada klinik kecantikan DRM Skin Clinic.

Hal ini sejalan dengan pendapat Payne (2000:189) bahwa promosi merupakan alat yang digunakan perusahaan jasa untuk berkomunikasi dengan pasar sasaran. Dalam bauran komunikasi terdapat variasi luas dari alternatif alat komunikasi yang dapat dipergunakan dalam suatu program komunikasi. Lebih lanjut Payne mengatakan bahwa promosi jasa mencangkup bidang utama yang dikenal dengan bauran komunikasi atau bauran promosi, meliputi unsur-unsur: periklanan, penjualan personal, promosi penjualan, hubungan masyarakat, word of mouth, dan direct marketing.

Hal ini sejalan pula dengan pendapat Ginting (2003) dalam penelitiannya yang berjudul "Pengaruh bauran pemasaran jasa terhadap keputusan peserta didik dalam memilih LBB Primagama Malang" dimana promosi berpengaruh paling dominan dalam keputusan pembelian konsumen. Selain itu, temuan ini juga mendukung penelitian oleh Sukotjo dan Radix (2010) yang berjudul "Analisa marketing mix 7-P (produk, price, promotion, place, participant, process, dan physical evidence) terhadap keputusan pembelian produk klinik kecantikan Teta di Surabaya" dimana promosi berpengaruh paling dominan dalam keputusan pembelian konsumen.

\section{Pengaruh Partisipan Terhadap Keputusan Konsumen Dalam Pembelian Produk}

Berdasarkan hasil perhitungan analisis regresi linear berganda dengan pengujian secara parsial diketahui bahwa variabel partisipan $\left(X_{5}\right)$ diperoleh koefisien sebesar 0,020, t-hitung 0,223 dan nilai signifikansi 0,824 yang berarti jika terdapat peningkatan terhadap orang 1 satuan maka akan meningkatkan keputusan konsumen perawatan kulit pada klinik kecantikan DRM Skin Clinic sebesar 0,304 satuan. Dengan kata lain setiap ada perubahan atau penambahan nilai partisipan akan meningkatkan keputusan konsumen perawatan kulit pada klinik kecantikan DRM Skin Clinic.

Hal ini sejalan dengan pendapat Yazid (1999:20) bahwa partisipan atau people adalah semua pelaku yang memainkan sebagian penyediaan jasa dan karenanya mempengaruhi persepsi pembeli. Partisipan adalah setiap dan semua orang yang memainkan suatu peran dalam waktu riil jasa (selama berlangsungnya proses dan konsumsi jasa berlangsung). Ini termasuk semua 
Syarifuddin Arief, Pengaruh Bauran Pemasaran Terhadap Keputusan Konsumen Perawatan Kulit Pada Klinik

Kecantikan DRM Skin Clinic Di Makassar|129

karyawan dan konsumen. Semua pelaku yang berpartisipasi dalam penyajian jasa menjadi petunjuk tentang karakteristik maupun kualitas jasa yang akan diterima konsumen. Selain itu, menurut Payne (2000:33) orang-orang merupakan unsur yang penting, baik dalam produksi maupun penyampaian kebanyakan jasa. Orang-orang secara bertahap menjadi bagian diferensiasi yang mana perusahaan-perusahaan jasa mencoba menciptakan nilai tambahan dan memperoleh keunggulan kompetitif. Personil bagi pemasaran jasa sangat penting. Keberhasilan memasarkan suatu jasa berkaitan erat dengan seleksi, pelatihan, motivasi, dan manajemen sumber daya manusia. Personil bagi pemasaran jasa sangat penting. Keberhasilan memasarkan suatu jasa berkaitan erat dengan seleksi, pelatihan, motivasi, dan manajemen sumber daya manusia.

Hal ini sejalan pula dengan pendapat Zeithmal dan Bitner dalam Yazid (1999:165) menyatakan bahwa peran orang, dalam hal ini karyawan lini depan dan yang mendukungnya bagian belakang, sangat penting bagi keberhasilan setiap organisasi jasa. Karyawan adalah jasa itu sendiri, karyawan adalah organisasi di mata konsumen, dan karyawan adalah para pemasar. Temuan ini mendukung penelitian dari Kurniawan (2009) yang menyatakan bahwa variabel orang tidak berpengaruh terhadap keputusan konsumen.

\section{Pengaruh Proses Terhadap Keputusan Konsumen Dalam Pembelian Produk}

Berdasarkan hasil perhitungan analisis regresi linear berganda dengan pengujian secara parsial diketahui bahwa variabel proses $\left(\mathrm{X}_{6}\right)$ diperoleh koefisien sebesar 0,224, t-hitung 2,015 dan nilai signifikansi 0,047 yang berarti jika terdapat peningkatan terhadap proses 1 satuan maka akan meningkatkan keputusan konsumen perawatan kulit pada klinik kecantikan DRM Skin Clinic sebesar 0,224 satuan. Dengan kata lain setiap ada perubahan atau penambahan nilai proses akan meningkatkan keputusan konsumen perawatan kulit pada klinik kecantikan DRM Skin Clinic.

Hal ini sejalan dengan pendapat Payne (2000:210) bahwa proses menciptakan dan memberikan jasa pada pelanggan merupakan faktor utama dalam bauran pemasaran, karena pelanggan jasa akan memandang sistem pemberian jasa tersebut sebagai bagian dari jasa itu sendiri. Semua kegiatan pekerjaan adalah merupakan proses. Proses ini meliputi mekanisme pelayanan, prosedur, jadwal kegiatan serta rutinitas suatu jasa diberikan kepada pelanggan. Proses-proses dapat dipertimbangkan dengan dua cara yaitu dalam hal kompleksitas dan dalam hal divergensi. Kompleksitas berkaitan dengan karakteristik langkah-langkah dan urutan-urutan yang terdapat dalam proses tersebut, sementara divergensi mengacu pada ruang gerak atau variabilitas pelaksanaan langkah-langkah dan urutan-urutannya.

Hal ini sejalan pula dengan pendapat Lyn Shostack dalam Payne (2000:212) menyatakan bahwa proses merupakan unsur struktural yang dapat dikelola untuk membantu menyampaikan positioning strategik yang diharapkan. Sedangkan menurut Yazid (1999:22) proses yaitu semua prosedur aktual, mekanisme, dan aliran aktivitas dengan mana jasa disampaikan yang merupakan suatu sistem penyajian atau operasi jasa. Pada akhirnya, proses mencerminkan bagaimana elemen bauran pemasaran dikoordinasikan untuk menjamin kualitas dan konsistensi jasa yang diberikan kepada konsumen. Temuan ini mendukung penelitian dari Irwinda (2011) mengenai " Pengaruh Marketing Mix Terhadap Keputusan Konsumen Yang Menabung Pada PT.Bank Mandiri 
130|Ad'ministrare, Vol. 3 No. 2, 2016

(Persero) Tbk, Cabang Makassar Kartini" yang menyatakan bahwa variabel proses merupakan variabel yang berpengaruh dominan terhadap keputusan pembelian konsumen.

\section{Pengaruh Lingkungan Fisik Terhadap Keputusan Konsumen Dalam Pembelian Produk}

Berdasarkan hasil perhitungan analisis regresi linear berganda dengan pengujian secara parsial diketahui bahwa variabel lingkungan fisik $\left(\mathrm{X}_{7}\right)$ diperoleh koefisien sebesar 0,156, t-hitung 2,036 dan nilai signifikansi 0,045 yang berarti jika terdapat peningkatan terhadap lingkungan fisik 1 satuan maka akan meningkatkan keputusan konsumen perawatan kulit pada klinik kecantikan DRM Skin Clinic sebesar 0,156 satuan. Dengan kata lain setiap ada perubahan atau penambahan nilai lingkungan fisik akan meningkatkan keputusan konsumen perawatan kulit pada klinik kecantikan DRM Skin Clinic.

Hal ini sejalan dengan pendapat Yazid (1999:21) bahwa bukti fisik adalah lingkungan fisik dimana jasa disampaikan dan dimana perusahaan dan konsumennya berinteraksi dan setiap komponen tangibel menfasilitasi penampilan atau komunikasi jasa tersebut. Hal ini sejalan pula dengan pendapat Payne (2000:164) bahwa bukti-bukti fisik dapat dibagi menjadi dua jenis, yaitu: essential evidence dan peripheral evidence. Dalam mendesain fasilitas-fasilitas tersebut, perlu diperhatikan keadaan lingkungan secara keseluruhan dan juga harus memperhatikan bagaimana pengaruhnya terhadap kinerja karyawan dan pelanggan. Temuan ini mendukung penelitian oleh Kurniawan (2009) mengenai "Pengaruh bauran pemasaran terhadap keputusan konsumen memilih jasa pencucian mobil (study pada CV. Al Kahfi Malang)" dimana variabel bukti fisik memberi pengaruh paling dominan terhadap keputusan pembelian konsumen.

\section{SIMPULAN}

Berdasar pokok permasalahan, tujuan penelitian, hasil analisis dan pembahasannya, maka dapat dikemukakan kesimpulan sebagai berikut :

1. Terdapat pengaruh positif dan signifikan bauran pemasaran (produk, harga, lokasi, promosi, partisipan, proses, dan lingkungan fisik) terhadap keputusan konsumen perawatan kulit pada klinik kecantikan DRM Skin Clinic secara simultan. Hal ini dibuktikan dengan nilai $F$ hitung yang lebih besar dari nilai Ftabel $(57,242>2,115)$ dan nilai P yang lebih kecil dari $\alpha(0,000<0,05)$.

2. Terdapat pengaruh positif dan signifikan variabel produk, lokasi, promosi, proses, dan lingkungan fisik terhadap keputusan konsumen perawatan kulit pada klinik kecantikan DRM Skin Clinic secara parsial. Hal ini dibuktikan dengan nilai t hitung yang lebih besar dari nilai $t$ tabel $(1,987)$. Variabel produk memiliki nilai t hitung sebesar 2,138 $(\mathrm{p}=0,035)$, variabel lokasi memiliki nilai t hitung sebesar 2,057 $(\mathrm{p}=0,043)$, variabel promosi memiliki nilai t hitung sebesar 2,900 $(\mathrm{p}=0,005)$, variabel proses memiliki nilai t hitung sebesar 2,015 ( $\mathrm{p}=0,047)$, dan variabel lingkungan fisik memiliki nilai $\mathrm{t}$ 
Syarifuddin Arief, Pengaruh Bauran Pemasaran Terhadap Keputusan Konsumen Perawatan Kulit Pada Klinik Kecantikan DRM Skin Clinic Di Makassar|131

hitung sebesar 2,036 ( $\mathrm{p}=0,045)$. Variabel harga berpengaruh negatif namun tidak signifikan, dengan nilai t hitung sebesar $-0,600(\mathrm{p}=0,550)$, dan variabel partisipan berpengaruh positif namun tidak signifikan dengan nilai $\mathrm{t}$ hitung sebesar $0,223 \mathrm{c}=$ 0,824 ). Variabel yang paling dominan pengaruhnya terhadap keputusan konsumen perawatan kulit pada klinik kecantikan DRM Skin Clinic adalah variabel promosi dengan nilai t hitung terbesar $(2,900)$ dan nilai signifikansi terkecil $(0,005)$.

3. Terdapat korelasi yang sangat kuat antara variabel bauran pemasaran (produk, harga, lokasi, promosi, partisipan, proses, dan lingkungan fisik) dengan keputusan konsumen perawatan kulit pada klinik kecantikan DRM Skin Clinic. Hal ini dibuktikan dengan nilai korelasi $(\mathrm{R})$ sebesar 0,905 yang signifikan pada $\alpha=0,000$.

4. Kontribusi variabel-variabel bebas dalam menjelaskan variasi variabel terikat adalah besar, hal ini dibuktikan dengan koefisien determinasi $\left(\mathrm{R}^{2}\right)$ sebesar 0,820 (82\%). Sedangkan sisanya $18 \%$ dijelaskan oleh variabel-variabel lain diluar variabel yang diteliti.

\section{DAFTAR PUSTAKA}

Alma, Buchari. 1998. Manajemen Pemasaran dan Pemasaran Jasa. Bandung: CV Alfabeta.

Ginting. 2003. Pengaruh Bauran Pemasaran Jasa Terhadap Keputusan Peserta Didik Dalam Memilih Lembaga Bimbingan Belajar Primagama Malang. Skripsi. Tidak diterbitkan. Malang. Fakultas Ekonomi. Unibraw.

Irwinda. 2011. Pengaruh Marketing Mix Terhadap Keputusan Konsumen Yang Menabung Pada PT.Bank Mandiri (Persero) Tbk, Cabang Makassar Kartini”. Skripsi. Tidak diterbitkan. Makassar. Fakultas Ekonomi. Unhas.

Kotler, Philip. 1997. Manajemen Pemasaran: Analisis, Perencanaan, Implementasi, dan Kontrol. Jilid I. Jakarta: PT Prenhallindo.

Kurniawan, Danang. 2009. Pengaruh Bauran Pemasaran Terhadap Keputusan Konsumen Memilih Jasa Pencucian Mobil (Study pada CV. Al Kahfi Malang). Skripsi. Tidak diterbitkan. Malang. Fakultas Ekonomi. Unibraw.

Payne, Adrian. 2000. The Essence Of Service Marketing Pemasaran Jasa. Alih bahasa: Fandy Tjiptono. Yogyakarta: Andi.

Sukotjo, Hendri dan Radix Sumanto A. 2010. Analisa Marketing Mix 7-P (Produk, Price, Promotion, Place, Participant, Process, dan Physical Evidence) Terhadap Keputusan Pembelian Produk Klinik Kecantikan Teta di Surabaya. Jurnal Mitra Ekonomi dan Manajemen Bisnis, Vol.1, No.2. 216-228. 
132 |Ad'ministrare, Vol. 3 No. 2, 2016

Sugiyono.2004. Metode Penelitian Administrasi. Bandung: Alfabeta.

Warsis. 2007. Pengaruh Bauran Pemasaran Jasa Terhadap Keputusan Konsumen Memilih Travel” (Studi Kasus Pada Kirana Tour \& Travel Malang). Skripsi. Tidak diterbitkan. Malang. Fakultas Ekonomi. Unibraw.

Yazid. 1999. Pemasaran Jasa: Konsep dan Implementasi. Yogyakarta: Ekonisia FE UII. 